\title{
Sheep Breeder Empowerment inParticipatory Model of Koperasi Mitra Subur at Bondowoso Regency East Java
}

\author{
Tanti Kustiari ${ }^{1}$, Anita Yuliana ${ }^{2}$, Fredy Eka Ardhi Pratama ${ }^{3}$ \\ ${ }^{1,3}$ Manajemen Agribisnis, Politeknik Negeri Jember \\ ${ }^{2}$ Mahasiswa Agribisnis, Politeknik Negeri Jember \\ tanti_kustiari@polije.ac.id
}

Received: 12 Januari 2021; Revised: 26 Februari 2021; Accepted: 28 April 2021

DOI: http://dx.doi.org/10.37905/aksara.7.2.347-354.2021

\begin{abstract}
Abstrak
Program pemberdayaan mitra pada koperasi Ternak Tani Syariah Mitra Suburpola kemitraansistem bagihasil Syariah dan investasi. Tujuan meningkaktan kemampuan usaha ternak domba peternak mitra. Metode pemberdayaan yaitu FGD, wawancara mendalam untuk diperoleh prioritas masalah dan kesepakatan pemecahan masalah serta penyuluhan. Masalah utama mitra adalah ketersediaan pakan alternatif yang optimal dalam rangka peningkatan produktivitas hasil. Stakeholder yang terlibat adalah fasilitator dari akademisi, penyuluh, pengelola dan mitra peternak domba. Program pelatihan pembuatan pakan hijauan dan pakan berbasis limbah potensial lokal. Pakan hijauan rumput jagung dihasilkan dari budidaya jagung dengan cara hidroponik. Pelatihan pembuaant pakan alternatif dari limbah jerami padi yang banyak tersedia di lahan. Jerami padi difermentasi. Berdasarkan hasil pre test dan post test diperoleh hasil bahwa pengetahuan dan ketrampilan peternak domba menunjukkan peningkatan.
\end{abstract}

\section{Kata Kunci : Domba, Peternak, Kemitraan, Pelatihan}

\begin{abstract}
The program of sheep breeders with a participatory empowerment model is to increase the business capacity. The methods are FGD, in-depth interviews to obtain priority problems, and agreement on problem-solving and counseling. The main problem is the availability of alternative feed. Stakeholders that are involved are a team of academics, extension workers, managers, and partners of sheep breeders. Twenty sheep breeders participated in the training using demonstration methods of making forage and feed based on local potential waste. Corn grass feed is produced from the cultivation of hydroponics maize. In addition to forage feed, sheep breeders learn to make an alternative feed from rice straw waste which is widely available in the land. Fermented rice straw. Based on the results of the pre-test and post-test, it was found that the knowledge and skills of the sheep breeders showed an increase. The training activities for the manufacture of forage feed and fermented hay feed are alternative feeds as feed reserves during the dry season.
\end{abstract}

Keywords--Sheep, Breeder, Partnership, Training

\section{INTRODUCTION}

Bondowoso is one of the districts that have the potential to develop cattle, goats, and sheep. The number of goats and sheep in Bondowoso in 2019 had reached 90,107 heads, with details of the number of goats amounting to 47,170 heads and sheep of 
42,937 heads (BPS 2019) [1]. Data for sending or receiving sheep is quite dense, namely the delivery of goats for 5668 heads, 10,438 sheep and 2786 for incoming livestock, 3594 for sheep (BPS 2019) [1], indicating a fairly dense flow of livestock traffic. The majority of the community's livelihood characteristics in Bondowoso Regency are farming and livestock with a total of 193,673 people, working in the industrial sector of 73,168 people, in the service sector of 152,656 people.

Demand for public consumption of meat, in 2019, was met by slaughtering 7,606 cattle, 17,049 goats, and 19,149 sheep. The number of sheep that were slaughtered has increased (BPS 2019). The need for lamb for the people of Bondowoso Regency is high for various needs including religious events, parties, culinary delights in restaurants and restaurants. The prospect of developing a livestock business can be conducted by cultivating seed propagation. The national sheep business is mostly carried out by small farmers in rural areas (Wibowo et al., 2016) [2].

Koperasi Tani Ternak Syariah (KTTS)in Karanganyar Village, Tegalampel District, was established as a forum for creating jobs for the surrounding community. KTTS provides sharia-based services that provide many conveniences in partnership, capitalization, marketing of livestock products with guaranteed stable and fair prices. The ease and convenience of the services offered have an impact on the advancement of KTTS within the reach of the target area up to Jember Regency.

Community empowerment activities for sheep breeder partnerships with a participatory model are partners actively involved in activities [3]. Based on the results of the observations, the FGD obtained an agreement on the priority of solving problems in the livestock business of human resources in partnership with sheep breeders. This is based on the various conditions and capabilities of livestock businesses and has an impact on various livestock production results. Also, the limitations of the cooperative in fulfilling concentrate feed for all partners of sheep breeding and fattening, especially during the dry season. The dry season causes the availability of feed in limited quantities.

The priority problem of partnership sheep breeders is the limited forage during the dry season. In the context of empowering breeders to be able to make alternative reserve forage, the relevant empowerment programs are training in making young maize leaf forage and training on processing rice straw waste as an alternative reserve feed for partners of sheep fattening and breeding. The objective of the empowerment program is that partners can provide feed independently by utilizing abundant natural resource potentials [4], namely processing rice straw waste. The long-term goal is that partners can increase nursery production and increase the production of sheep.

\section{METHOD}

1 Problem Solving Approach

Capacity-building activities of Koperasi Mitra Subur breeders begin with the activity of FGD (Focus Group Discussion), in-depth interviews that aim to obtain various information on needs, hopes to be achieved, and resolved. FGD can produce problem-solving solutions [5]. Interviewees directly determine the priority scale of activities and materials. Identification and determination of the priority scale of the problem are determined together with Interviewees consisting of breeders, partnership managers together with facilitators to determine an agreement on an empowerment program to increase the capacity of livestock businesses, especiallyKoperasi Mitra Subur sheep partnership breeders, namely a training program for 
making forage for sheep breeders and training in manufacturing dry feed for sheep fattening breeders.

2. Scope of Activities and Instruments required

The scope of training activities includes the manufacture of forage and feed production based on local waste availability. Forage made from maize. Maize seeds are planted hydroponically to obtain young corn leaves. Corn leaves can be used as sheep feed. Making animal feed from an abundance of local waste materials, namely straw. The straw is fermented with probiotic powder so that it can produce long-lasting dry animal feed.

The instruments needed in the feed-making training program are pre-test and post-test questionnaires, hydroponic agricultural land and installations, training guides, training materials, and teaching aids.

3. Organizational History

Koperasi Mitra Subur was founded by a young man who was followed by the Karanganyar Village livestock group. Partnership cooperatives are based on the principles of justice, openness, mutual synergy. In 2015 the cooperative became a legal entity under the name Koperasi Tani Ternak Syariáh Mitra Subur or abbreviated as KTTS Mitra Subur. There are 2 types of business fields, namely cattle and sheep farming. In 2021 there will be 250 cows being raised

In 2021, 205 sheep breeder partners joined. The sheep breeder partners service area covers 2 districts, namely Jember and Bondowoso, which are spread across 14 subdistricts. At this time the sheep population was 3570 heads.

\section{KTTS Mitra Subur Institution}

The cooperative is engaged in financing, savings according to the Sharia profit sharing and investment system. It aims to help improve the economy and welfare of its members and society in general and to build the Indonesian economy according to Islamic principles. The function of a Sharia Cooperative is to build and develop all the potential that exists in each of its members as well as to improve the economic welfare of the community in general, improve the quality of human resources of its members to be more trustworthy, professional, consistent and consistent in carrying out economic principles.

Opening and expanding employment opportunities for members and the wider community. Help grow and develop various productive businesses of cooperative members. There are 7 values of Islamic cooperatives, namely honesty, consistency, transparency, trust, professional ethos, the spirit of solidarity, responsibility.

5. Solutions Offered

Based on the results of observations and problem identification, the solution is training in making forage. Forage feed from maize seeds planted hydroponically and forage from rice straw by fermentation.

Training in making young maize leaf feed was given to partner nurseries. Training on making forage from rice straw was given to sheep fattening partners.

6. Place and Time of Implementation

FGD activities, interviews were held at KTTS Mitra Subur in Karanganyar Village, Tegal Ampel District, Bondowoso, from October to January 2021. Training activities were held at partner locations in Sumbersalak village, Bondowoso. The offline training activity was attended by 20 partner breeders of fattening and breeding sheep. The number of breeders is limited to 20 people to prevent potential transmission of Covid-19.

7 Approaches and Methods 
The training program is non-formal education whose programs need to be designed according to the problems and needs of partners. Program implementation runs efficiently if there are supporting factors [6], namely methods of discussion and demonstration. Supported by materials and props for the manufacture of forage, questionnaires for assessment of learning outcomes. Also, it is supported by the availability of tools and equipment for making forage, namely baskets, corn kernels, hand spray, probiotics, and rice straw.

The training is carried out offline by paying attention to health protocols to prevent the transmission of covid-19. The activity begins with a pre-test to assess learning readiness. The activity of making feed was demonstrated to 20 participants. For evaluation, post-test of partner learning outcomes was carried out at the end of the activity

\section{DISCUSSION AND RESULT}

Activity Results

As many as 20 partners participated in the training program for the manufacture of sheep forage, with the characteristics of being a partner between 1 - 5 years, and 1 10 years of farming experience. As much as $70 \%$ partner fattening, 30\% partner nursery.

The two types of partnerships, namely sheep fattening and sheep breeding partners, are participants in training activities for making forage because partners need information and experience in making reserve forage. The ability to independently produce the availability of alternative forage feed is a solution when there is limited availability of concentrate feed.

Training on Making Forage Using Corn

The practice of making forage is carried out with the facilitator and partner sheep breeders. The following is the activity of making forages from hydroponically grown maize seeds.

1. Prepare the ingredients, namely $1 \mathrm{~kg}$ of maize seeds and sufficient water.

2. Prepare the equipment, namely a plastic tray with a small hole in the bottom. Wooden shelf and hand spray

3. Soak the maize seeds for 24 hours, then drain them.

4. Do the sowing of maize seeds on a plastic tray.

5. Spray 3 times per day for 7 days.

6. Store the maize seeds for 7 days until the leaves grow as high as $25 \mathrm{~cm}$.

7. Harvest young corn leaves, then give to the adult sheep.
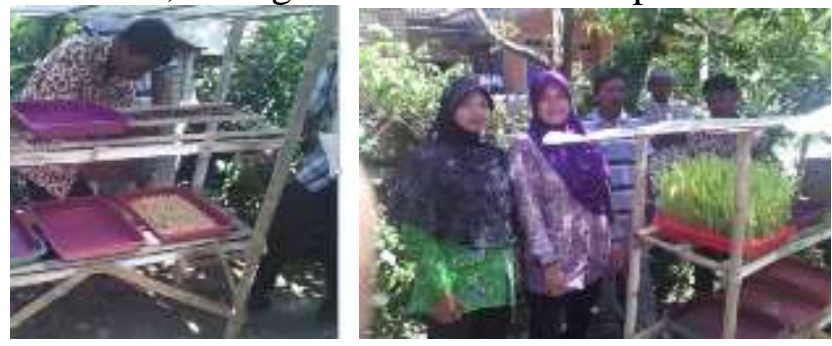

Picture 1 The Practice of Making Forage Feed from Young Corn Leaves Hydroponically

\section{Training on Making Rice Straw Animal Feed (Forage)}

The practice of making rice straw fermented forage was followed by the sheep partnership participants. Here are the activities. 
1. Prepare the ingredients, namely fresh rice straw with a water content of $60 \%, 10 \mathrm{~kg}$ of tupi bran, $2.5 \mathrm{~kg}$ of powdered probiotic, $4 \mathrm{~kg}$ of salt urea, and additives.

2. Arrange straw in layers with a thickness of $30 \mathrm{~cm}$ each layer. Each layer is sprinkled with a thin layer of bran, and sprinkled with a mixture of probiotics and urea, and sprinkle with salt.

3. Place the straw in a place that is shaded from the sun. Then cover tightly with a tarp or plastic.

4. On days 14-21 fermentation of rice straw can be used as animal feed

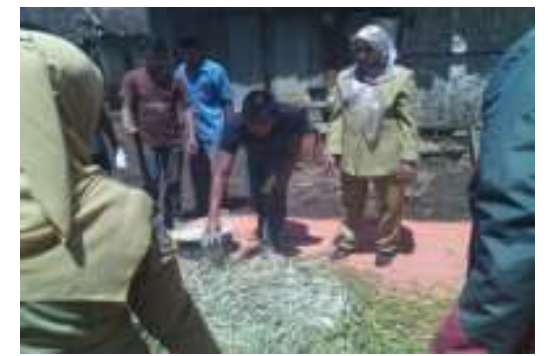

Picture 2. The Practice of Making Rice Straw Fermented Forage Feed Evaluation of Learning Outcomes of Sheep Partnership Breeders

The results of farmer learning assessments can be seen in the results of changes in knowledge and skills. See Table 1.

Table. 1. Assessment of Farmer Learning Outcomes

\begin{tabular}{|c|c|c|}
\hline No & Scoring Aspect & Results \\
\hline 1 & $\begin{array}{l}\text { The process of making young } \\
\text { corn leaf feed }\end{array}$ & $\begin{array}{l}\text { There is an increase in knowledge } \\
\text { and understanding }\end{array}$ \\
\hline 2 & $\begin{array}{l}\text { The process of making forage } \\
\text { rice straw fermentation }\end{array}$ & $\begin{array}{l}\text { There is an increase in knowledge } \\
\text { and understanding }\end{array}$ \\
\hline 3 & $\begin{array}{l}\text { The practice of making } \\
\text { forage of young corn leaves }\end{array}$ & There is an increase in ability \\
\hline 2 & $\begin{array}{l}\text { The practice of making } \\
\text { forage of rice } \\
\text { fermentation }\end{array}$ & There is an increase in ability \\
\hline 3 & $\begin{array}{l}\text { Benefits of using forage of } \\
\text { leaves young corn }\end{array}$ & There is an increase in knowledge \\
\hline 3 & $\begin{array}{l}\text { Benefits of using forage of } \\
\text { rice strawfermentation }\end{array}$ & There is an increase in knowledge \\
\hline
\end{tabular}

The training activities consist of extension activities and feed making practices. After the training activities ended, all trainees were given guidance on making feed and livestock business management techniques. At the end of the training, all breeders were assessed based on the results of the post-test.

All participants who have participated in the training activities are given a certificate of appreciation. The award charter is a document that can be used as evidence of one of the proof documents of the achievement of mastery of the knowledge and skills of a sheep partnership breeder. 


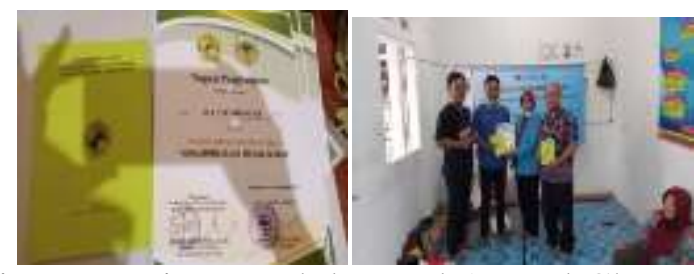

Picture 3. Giving Learning Modules and Award Charter to KTTS Mitra Subur Partners

\section{Discussion}

In the discussion section, an important point that shall be discussed, at least five discussions. First, it appears that there is a link between the results obtained and the basic concept. The community service program is aimed at the sheep and cattle husbandry partnership agency KTTS Mitra Subur Bondowoso.

Problem-solving with the Focus Discussion Group (FGD) method, interviews, and direct implementation of the strategies that have been designed to successfully find the problem of KTTS Mitra Subur lies in the Human Resources (HR) of partnership breeders. Low knowledge, insight, and skills in livestock business. The mindset in raising livestock that still follows tradition has not maximally utilized existing livestock management science and technology.

Based on the results of the agreement on a limited discussion of the management, partnership breeders, and community service program facilitators, agreed on priority training needs related to forage and its supporting materials.

Based on the pre-test results, it shows that the trainees have not mastered the material on livestock business and the practice of making alternative forages. Based on the identification of the various needs of trainees, the material for making feed is expanded to the technical management of livestock businesses. Trainees were given technical counseling material for making feed and technical material for feeding and maximizing the potential of local waste as forage feed which can be increased in value using fermentation.

The knowledge of partnership breeders of sheep has different views in terms of the important material or not the importance of forage (HMT) for sheep and the proportion of HMT with concentrate dry feed. The difference in views among breeders is due to differences in the results of livestock business experience and differences in the success of livestock productivity achievements. Among the ability to achieve low livestock productivity, some breeders have succeeded in achieving productivity results from breeding, and fattening results from sheep meat. Its success is due to the use of HTM. Therefore, in this training, breeders are given a discussion space and given learning experiences to make alternative forage feeds. It is expected that the experience of practicing the manufacture of forage feed can be implemented in each livestock business. To support the smooth implementation of alternative HTM, partnership breeders are given guidance on livestock business management. The goal is that breeders can follow technical SOPs for making feed and technical feed-giving supplemented with general materials for sheep cultivation, both breeding, and fattening. It is expected that the partnership breeders will be able to increase the achievement of livestock production. Increasing the productivity of the livestock business is certainly expected to have a positive impact on increasing the productivity and income of the 
KTTS Mitra Subur farm with its partners.

Community service program with training activities involves stakeholders. Several parties were involved in these activities. Training and counseling have strengthened good cooperative relations between partners, KTTS Mitra Subur managers, facilitators at the State Polytechnic of Jember, and the Bondowoso Regency Agriculture Service.

\section{CONCLUSION}

The participatory empowerment program involves related parties, namely partners, the management of the KTTS Mitra Subur partnership institution, teaching staff and Polije postgraduate students, the Agriculture Office.

Community empowerment activities begin with problem identification, determination of problem priorities, and problem-solving agreements. At the end of the activity, an evaluation was carried out on the implementation of the training activities and the awarding of certificates of appreciation to the training participants.

The training activities have contributed to increasing knowledge and skills in making forage from corn kernels and rice straw waste. The training also provided technical support materials for the use and provision of feed following the SOP and livestock business materials. The feed-making learning module is given to all partners as a guide in working on partnership sheep breeding.

\section{REFERENCE}

BPS. 2019. KabupatenBondowoso Dalam Angka.Badan Pusat Statistik. Kabupaten Bondowoso. Kab. bondowoso.go.id.

Wibowo, B., S. Rusdiana, dan U. Adiati. (2016). PemasaranTernakDomba di Pasar Hewan PalasariKabupatenIndramayu. Agriekonomika, 5(2). 85-93.

Kustiari, Tanti dan Rizal. 2018. Penyuluhan Pertanian. Panduan Pembelajaran bagi Pendidikan Vokasional. Yogyakarta : Penerbit Media Pustaka

Sari, T.A. I.Yolanda. F.F Nur Fikri. D. Aulia. S.S Faruk. W.Aprilia. 2020. Fermentasi Limbah Jerami dan Sempelah Tahu sebagai Pakan Ternak Alternatif di Desa Jaya Mekar Kecamatan Cibugel Kabupaten Sumedang. LOGISTA-Jurnal Ilmiah Pengabdian kepadaMasyarakat, [S.1.], v. 4, n. 2, p. 429-434, dec. 2020

Nurhaifa, Italyani. Ghullam Hamdu, Yusuf Suryana. 2020.Rubrik Penilaian Kinerja pada Pembelajaran STEM Berbasis Keterampilan 4C. Indonesian Journal of Primary Education. Vol. 4, No. 1 (2020) p. 101-110

Kustiari, Tanti dan M.T. Hidayatullah. 2017. Teknik Pembelajaran Dalam Penyuluhan. Jember: UPT Penerbitan Universitas Jember. 
AKSARA: Jurnal Ilmu Pendidikan Nonformal

P-ISSN $\underline{2407-8018}$ E-ISSN $\underline{2721-7310}$ DOI prefix $\underline{10.37905}$

Volume 07 (02) Mei 2021

http://ejurnal.pps.ungac.id/index.php/Aksara

354 AKSARA: Jurnal Ilmu Pendidikan Nonformal 